\title{
数種常緑広葉樹の光合成・蒸散速度の日変化と季節変化について
}

\author{
小杉緑子*・小橋澄治**・柴田昌三**
}

\section{Analysis on Diurnal and Seasonal Variation Pattern of Transpiration and Net Assimilation Rate of Several Evergreen Broad-leaved Trees}

\author{
Kosugi, Yoshiko*, Kobashi, Sumiji**, Shibata, Syozo**
}

要旨

大気一植物間の物質交換過程を解明するために, 数種常緑広葉樹 (アラカシ・クスノキ・ マテバシイ）の個葉上での蒸散速度および光合成速度の通年測定結果を用いて解析を行っ た。測定結果から明らかになった蒸散速度および光合成速度の日変化および季節変化のパ ターンは, (1)日変化では光合成速度が午前中にピークを持つのに対し, 蒸散速度は正午ご ろピークを持ち, (2)季節変化では光合成速度より蒸散速度のほうが夏と冬の差が大きい, (3)この結果水利用効率は午前中のほうが午後より高く, また冬のほうが夏より高くなる, というものであった。そこで, $\mathrm{CO}_{2}$ および $\mathrm{H}_{2} \mathrm{O}$ フラックスを決定する要因を, 電気回路ア ナログモデルにおける勾配および抵抗の概念を用いて整理し，蒸散速度抢よび光合成速度 を決める生理要因を気孔コンダクタンスおよび葉内コンダクタンスの二つのパラメータを 用いて定量的に評価することを試みた。これらの結果から, 植物の気孔開閉が蒸散および 光合成速度をどの程度制御しているのかを定量的に表現することができた。また苲散およ び光合成速度の日変化および季節変化のパターンが大気または植物のどの要因に最も大き く影響されているのかを，水利用効率を分析することで説明した。

\section{1. はじめに}

植生被覆と環境との相互作用を理解する上で欠くこと のできない要素として，大気一植物一土畩間の物質交換 や熱交換過程があげられる。これらは主に植物の光合成 と蒸散過程を通して行われるため，この二つの過程を統 合的に理解することが重要になってくる。植物の光合成 と蒸散過程を理解する上で非常に重要な点は, この二つ の異なる過程, すなわち大気一植物間の $\mathrm{H}_{2} \mathrm{O}$ と $\mathrm{CO}_{2}$ の 交換が，葉の気孔という同一の経路を通って行われると

キーワード：蒸散速度, 光合成速度, 気孔コンダクタンス, 葉 内コンダクタンス, 水利用効率

Key words : Transpiration rate, Net $\mathrm{CO}_{2}$ assimilation rate, Stomatal conductance, Internal conductance, Water-use efficiency

* 京都大学農学部, 日本学術振興会特別研究員 Fac. of Agriculture, Kyoto Univ. JSPS Research Fellow

** 京都大学農学部

Fac. of Agriculture, Kyoto Univ.
いう点である。そこで，植物ができるだけ少ない水の損 失で, 最大の光合成量が得られるように気孔開閉によっ て自律的な制御を行うといったようなことがよく定性的 にいわれている。

従来は光合成速度と蒸散速度を同時に測定する例が測 定の困難さから少なかったため, この方面の統合的研究 は進まなかったが, 近年携帯式光合成蒸散測定装置の開 発と普及で両者の野外における非破壊・短時間での同時 測定が可能となったので，この方法による測定結果も報 告されるようになってきた。このような流れを受けて始 められた本研究5,9,11) の目的の一つは, 大気一植物間の $\mathrm{H}_{2} \mathrm{O}$ と $\mathrm{CO}_{2}$ の交換過程，すなわち蒸散・光合成がどのよ うな物理的また生理的特性によって決定されるのかを明 らかにし，その特性が環境条件でどのように変動するか を明らかにすることによって，環境条件から光合成およ び蒸散速度を推定できるモデルを構築することにある。

このような観点から, 数種常緑広葉樹（アラカシ・ク 
スノキ・マテバシイ）の個葉上での蒸散速度および光合 成速度の通年測定結果を用いて，大気および植物の各種 要因がどのようにまたどの程度蒸散および光合成速度の 変動パターンを規定しているかについて解析を行ったの で報告する。

\section{2. 解析および測定方法}

\section{1 解析方法}

蒸散および光合成速度の変動パターンは, 大気, 植物, 土壤の様々な要因によって決定されていると考えられ る。基本的には大気一植物間の $\mathrm{CO}_{2}$ および $\mathrm{H}_{2} \mathrm{O}$ フラッ クスの決定要因は，それぞれの物質の濃度勾配と拡散係 数であるが, これを便宜上電気回路のアナログモデルで 表すことがよく行われている。

このモデルでは, 基本的には蒸散速度 $\mathrm{E}\left(\mathrm{H}_{2} \mathrm{Omol} / \mathrm{m}^{2} /\right.$ sec) は,

$$
\mathrm{E}=\frac{\mathrm{g}_{\mathrm{bw}} \cdot \mathrm{g}_{\mathrm{sw}} \cdot\left(\mathrm{W}_{\mathrm{i}}-\mathrm{W}_{\mathrm{a}}\right)}{\mathrm{g}_{\mathrm{bw}}+\mathrm{g}_{\mathrm{sw}}}
$$

で表される。

$\mathrm{W}_{\mathrm{i}}$ : 気孔内の $\mathrm{H}_{2} \mathrm{O}$ モル分率で, 葉の細胞間隙が常に 水蒸気飽和状態であるという仮定から，測定さ れた葉温での飽和水蒸気圧 $(\mathrm{mb}) /$ 大気圧 $(\mathrm{mb})$ 。

$\mathrm{W}_{\mathrm{a}}$ : 葉外の $\mathrm{H}_{2} \mathrm{O}$ モル分率。

$\mathrm{g}_{\mathrm{bw}}$ : $\mathrm{H}_{2} \mathrm{O}$ 分子拡散についての葉面境界層コンダク タンスで, 定数 (ここでは $1.13 \mathrm{~mol} / \mathrm{m}^{2} / \mathrm{sec}$ )。

$\mathrm{g}_{\mathrm{sw}}$ : $\mathrm{H}_{2} \mathrm{O}$ 分子拡散についての気孔コンダクタンス。 蒸散活動によって水蒸気は土壌から植物を通って大気 中に放出されるが，根から吸収された水のうち光合成に 利用されるのは $1 \%$ に満たず（近藤，19827)，ほとん どは気孔を通して大気中に蒸散する。光合成に必要な二 酸化炭素を取り入れる必要から気孔を開くと，大気一植 物間の $\mathrm{H}_{2} \mathrm{O}$ 濃度勾配にドライブされて気孔から大気中 へ水蒸気が拡散する。このときの $\mathrm{H}_{2} \mathrm{O}$ フラックスは, 葉 面境界層コンダクタンスが一定の時は，上式から飽差と 気孔コンダクタンスで決定される。

次に純光合成速度 $\mathrm{A}\left(\mathrm{CO}_{2} \mu \mathrm{mol} / \mathrm{m}^{2} / \mathrm{sec}\right)$ は,

$$
A=\frac{g_{b c} \cdot g_{s c} \cdot\left(C_{a}-C_{i}\right)}{g_{b c}+g_{s c}}
$$

で表される。

$\mathrm{C}_{\mathrm{a}}$ : 葉外の $\mathrm{CO}_{2}$ モル分率。

$\mathrm{C}_{\mathrm{i}}$ : 細胞間吵の $\mathrm{CO}_{2}$ モル分率。

$\mathrm{g}_{\mathrm{bc}}: \mathrm{CO}_{2}$ 分子拡散についての葉面境界層コンダク タンス。 $\mathrm{g}_{\mathrm{bc}}=\mathrm{g}_{\mathrm{bw}} / 1.6^{(2 / 3)}$

$\mathrm{g}_{\mathrm{sc}}$ : $\mathrm{CO}_{2}$ 分子拡散についての気孔コンダクタンス。 $\mathrm{g}_{\mathrm{sc}}=\mathrm{g}_{\mathrm{sw}} / 1.6$
光合成活動は植物内での生化学的反応であり, 蒸散活 動を制御する生理的要因が気孔の開き具合いだけである のに比べ, 光合成に関しては複雑な葉内での反応が関連 している。光合成は光合成有効放射 (PAR) を吸収して クロロフィルで NADPH (ニコチンアミドアデニンジヌ クレオチドリン酸の還元型) と ATP (アデノシン三リン 酸）をつくる明反応と，これをエネルギー源としてカル ビン回路で炭酸同化をおこなう暗反応の二つの過程があ る。一方で $\mathrm{CO}_{2}$ 交換という観点からすると, 光合成活動 は蒸散と同様に大気一植物間の濃度勾配，気孔の開き具 合いおよび葉の二酸化炭素取り込み効率がフラックスの 決定要因と考えられる。光合成の場合, 葉内での生化学 的反応が二酸化炭素の取り込み効率を決定し，気孔の開 き具合いとあわせて葉の細胞間隙 $\mathrm{CO}_{2}$ 濃度が決まり,こ れによって濃度勾配が決定されることになる。自然条件 下での大気 $\mathrm{CO}_{2}$ 濃度の変動幅は水蒸気などに比べて小 さいので, 細胞間吵 $\mathrm{CO}_{2}$ 濃度と気孔の開き具合いが $\mathrm{CO}_{2}$ フラックスを主に規定することになる。一方で，これら の生理的反応も大気環境の影響を大きく受けている。

以上述べたことから，蒸散抢よび光合成速度を決定す る大きな要因の一つは濃度勾配であるが，このような外 的条件のほかに, 植物側の生理的要因を考慮にいれなけ れば蒸散・光合成速度の変動パターンを説明することが できないということがわかる。上述のモデルでは，気孔 コンダクタンスおよび細胞間隙 $\mathrm{CO}_{2}$ 濃度が植物の生理 的要因を表すパラメータとなっているが，気孔の開閉に よる植物の自律的制御が二酸化炭素の拡散をどの程度支 配しているのかを定量的に説明することができない。

そこで, 二酸化炭素の拡散については新たに葉内に抵 抗を一つ増やし, この逆数である葉内コンダクタンス $\mathrm{g}_{\mathrm{i}}$ という概念を導入した新たなモデル（ $g_{i}$ モデル）が提示 される。このモデルでは, (2)式は,

$$
A=\frac{g_{b c} \cdot g_{s c} \cdot g_{i} \cdot\left(C_{a}-\Gamma_{*}\right)}{g_{b c} \cdot g_{s c}+g_{s c} \cdot g_{i}+g_{i} \cdot g_{b c}}
$$

となる。

$\mathrm{g}_{\mathrm{i}}: \mathrm{CO}_{2}$ 分子拡散についての葉内コンダクタンス。 $\Gamma_{*}$ ：暗呼吸を考えない場合の $\mathrm{CO}_{2}$ 補償点（光合成細 胞内の $\mathrm{CO}_{2}$ モル分率)。

このような考え方は従来にも考察されているが2,4,8, 概念に生化学的現象に基づく厳密さを欠く点があること が指摘されてきだ)。しかし ${ }_{*}$ を FARQUHAR et al. $(1980)^{3)}$ の光合成モデル中の摂氏25度でのパラメータで ある31 $\mu$ bar および KIRSHBAUM and FARQUHAR $(1984)^{6)}$ の $42 \mu$ bar を参考に40 ppm 程度と仮定するこ とによって, 観測結果から葉内コンダクタンス $g_{1}$ の変動 
を実際に算出することができるため, 従来生理的現象と して不明瞭にされてきた $\mathrm{CO}_{2}$ の交換と $\mathrm{H}_{2} \mathrm{O}$ の交換がど のように連動するのかについての定量的な考察が可能に なるという点でおおきな意義があると考えられる。すな わち, 葉内コンダクタンス $\mathrm{g}_{1}$ は気孔コンダクタンスと同 じ dimensionをもち, 二つの抵抗による制御を定量的に 比較することができるという点坅重要性がある。

ここで，新たに定義された葉内コンダクタンスが実際 にはどのような生理的作用を表現しているのかが問題と なる。前述したように, 光合成活動は複雑な生化学的反 応を内包しているが, 統合モデル中の葉内コンダクタン スという概念は細胞間隙から光合成の場である葉肉細胞 の葉緑体内へのネットの $\mathrm{CO}_{2}$ 移動を想定し，これに関す る効率を表したものである。二酸化炭素を実際に消費す るのは光合成暗反応過程中のカルビン回路なので, 簡単 には $\mathrm{g}_{1}$ はカルビン回路の活性を示すパラメータと考え られる。図 1 にこのモデルによる二酸化炭素の拡散を概 念的に図示したが，実際の現象ではミトコンドリアで行 われる独自の過程である暗呼吸は, ネットの $\mathrm{CO}_{2}$ フラッ クスを考える便宜上モデル中では光合成過程に内包され る。 $\Gamma_{*}=40 \mathrm{ppm}$ という值は, 光合成暗反応過程での $\mathrm{PCO}$ 回路からの $\mathrm{CO}_{2}$ 放出だけを考慮に入れた場合, 葉 緑体内の $\mathrm{CO}_{2}$ 濃度がこの濃度で平衡していると考えた 值であり, 暗呼吸速度には影響されない。つまり, ここ での葉内コンダクタンス $\mathrm{g}_{1}$ は, (1)細胞間隙から葉肉細胞 内への $\mathrm{CO}_{2}$ の移動にかかる抵抗 (葉肉抵抗), (2)光合成暗

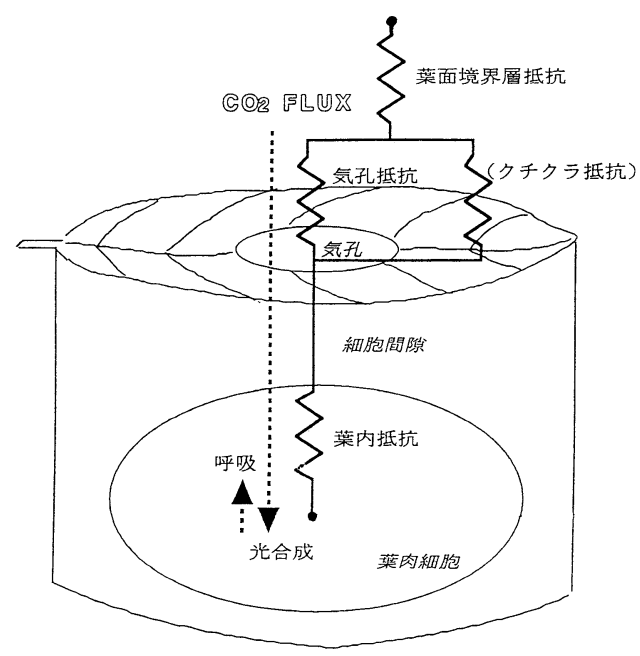

図 $1 \mathrm{~g}_{\mathrm{i}}$ モデルによる $\mathrm{CO}_{2}$ 拡散の考元方

Fig. 1 Conceptional figure of $\mathrm{CO}_{2}$ diffusion with $\mathrm{g}_{1}$ model
反応のカルビン回路活性，(3)暗呼吸速度の 3 つで決まる 值であり，(1)はまり変化しないので， $\mathrm{g}_{\mathrm{i}}$ は結局(2)(3)の 2 つの植物の生理的要因によって変わるパラメータと考 えることができる。また，この解析方法はプラスの $\mathrm{CO}_{2}$ フラックスが観測される場合にのみ適用することができ る。

\section{2 測定方法}

野外測定に使用した機器は携帯式光合成蒸散測定装置 （LI-6200，LI-COR 社）である。この装置は葉を挟み込 むチャンバーと, $\mathrm{CO}_{2}$ アナライザーおよびコンピュータ 一の 3 つの部分からなる。短時間での測定を行う必要か ら, 葉の一部を測定機器内に閉じ込める閉鎖系となって いる。本体内にはポンプが内蔵されており，葉を挟みチ ヤンバーを閉じると装置全体が閉鎖系となり, 空気が循 環する。基本的には，この閉鎖回路中の $\mathrm{CO}_{2}$ の変化率か ら純光合成速度（以下単に光合成速度とする）を, $\mathrm{H}_{2} \mathrm{O}$ の安定に必要な乾燥気体流量から蒸散速度を算出する。 この装置は同時に, 光量子量, 湿度, 温度の各センサー を備えており, 光合成有効放射, 葉温抢よびチャンバー 内の相対湿度, 気温, $\mathrm{CO}_{2}$ 濃度の測定を行う。また, こ れらの測定結果と前述の(1)(2)式で表される電気回路アナ ログモデルを用いて気孔コンダクタンスおよび細胞間隙 $\mathrm{CO}_{2}$ 濃度を算出する。この装置による測定結果はいくつ かの仮定を前提としているが,このうち最も重要なのは, チャンバーの形状と風速を一定にしていることから葉面 境界層抵抗は絶えず一定值を取るとしている点である。 このことによって個葉上での気孔コンダクタンスを比較 的容易に算出できるのである。

\section{3. 測定結果}

\section{1 測定木および日時}

今回解析の対象とするデー夕は，樹木の光合成および 蒸散速度の季節変化を野外で追跡した調查結果であ $3^{5,9)}$ 。測定は1989年 6 月から翌年 3 月まで, 京都大学農 学部附属演習林本部試験地内に植栽されている 5 年生の アラカシ (Quercus glauca), クスノキ (Cinnamomum camphora), マテバシイ (Pasania edulis) 各 1 個体につ いて行った。測定日は 6 月 1 日，7月22日，8月 4 日， 9 月 24 日，10月25日，11月23日，12月28日，1月27日， 3 月 6 日の 9 回, いずれも晴天日を選んで, 夜明け前か ら日没までほほ 1 時間に一回の割合で測定を行った。測 定葉は各個体の南面する葉の地上 $1 \mathrm{~m}$ 抢よび $2 \mathrm{~m}$ の当 年葉各 1 枚で, 測定の結果, 高度の違いによる有意な差 はなかったので解析には 2 枚の平均值を各個体の代表值 として用いた。各測定木は樹高約 $3 \mathrm{~m}$ 前後で隣接して植 


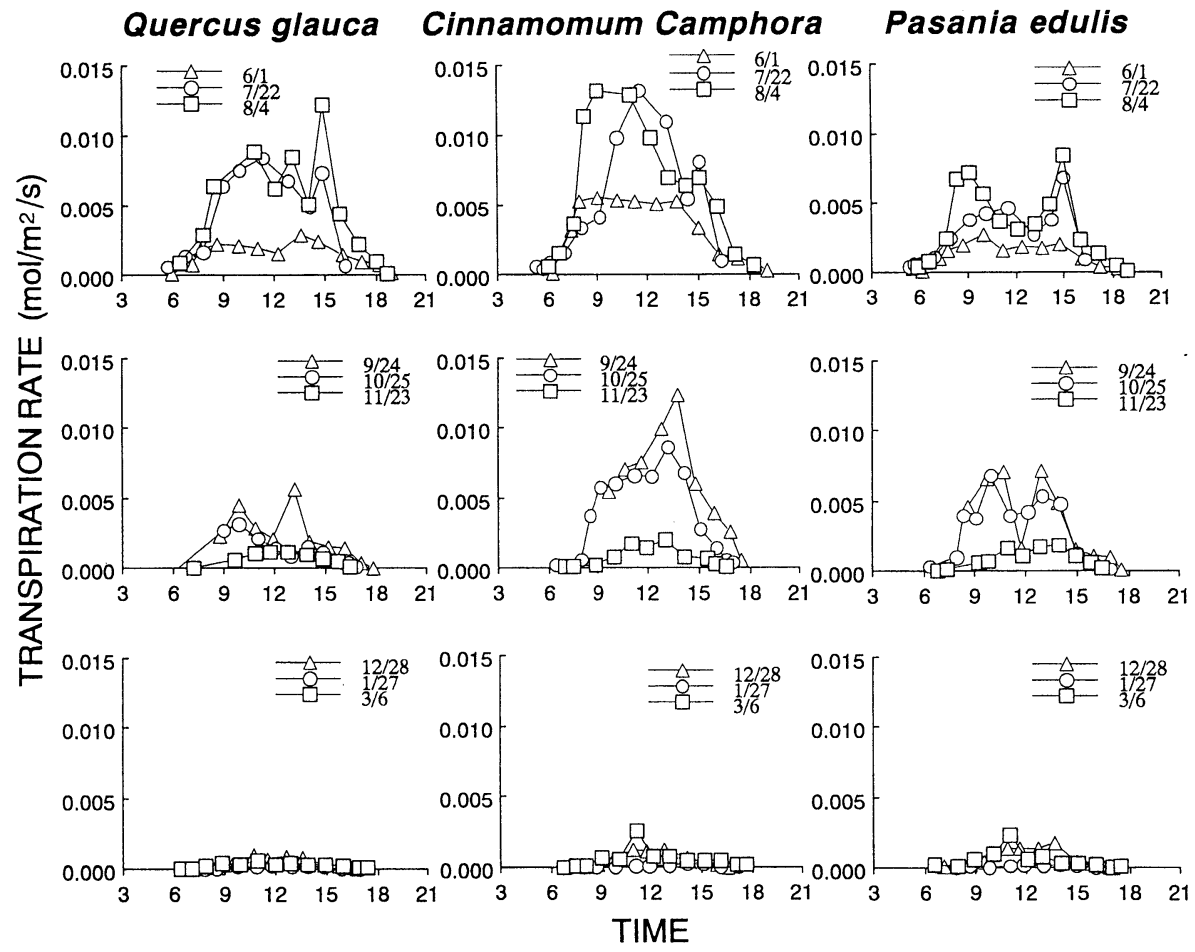

図 2 蒸散速度の日変化および季節変化

図は左列からアラカシ, クスノキ, マテバシイの各測定日における蒸散速度の経時変化を示している。図 3,4 , 6 も同様。

Fig. 2 Diurnal and seasonal variation of transpiration rate

栽されており，灌水は行っていないが測定期間を通じて 極端な土壌の乾燥はみられなかった。

\section{2 蒸散速度}

アラカシ，クスノキ，マテバシイ各葉の蒸散速度の日 変化および季節変化を図 2 に示す。蒸散速度の日変化は, 日中にピークをもつ山形もしくは台形の日が多かった。 ただし，8月の測定ではマテバシイにおいて顕著な日中 低下がみられた。季節変化では夏と冬の差が非常に顕著 で，冬はほとんど蒸散しない。また 7,8 月にピークが 見られ秋以降低下するアラカシ, クスノキに対して, マ テバシイでは秋でも夏と同様の蒸散活動が見られた。3 樹種の中ではクスノキの蒸散活動が一番盛んであった。

3.3 光合成速度

アラカシ，クスノキ，マテバシイ各葉の光合成速度の 日変化拉よび季節変化を図 3 に示す。光合成速度の日変 化は蒸散速度と違い, 午前中にピークをもつ山形の日が 多かった。 8 月の測定ではアラカシ，マテバシイにおい て日中低下が見られた。季節変化では蒸散と同様 7,8 月にピークが見られ秋以降低下するアラカシ, クスノキ
に対して, マテバシイでは秋でも夏と変わらない光合成 活動が見られた。光合成速度の冬に向けての低下は蒸散 速度ほど急激ではなかった。また, 蒸散と同様 3 樹種の 中ではクスノキの光合成活動が一番盛んであった。

\section{4 気孔コンダクタンス}

図 4 は左からアラカシ, クスノキ, マテバシイ各葉の $\mathrm{CO}_{2}$ 拡散についての気孔コンダクタンスの日変化打よ び季節変化を示したものである（以下気孔コンダクタン スの值はすべて $\mathrm{CO}_{2}$ 拡散についてのものを用いる)。気 孔コンダクタンスは最高でクスノキの $0.35 \mathrm{~mol} / \mathrm{m}^{2} / \mathrm{s}$ 程 度で, どちらかというと午前中のほうが大きい值をとっ ている日が多い。蒸散速度と同様冬の值は夏に比べてか なり小さい。また蒸散, 光合成速度の大きいクスノキで は気孔コンダクタンスも大きい值をとることがわかる。 またマテバシイの気孔コンダクタンスは蒸散・光合成と 同様秋でもあまり低下しなかった。 


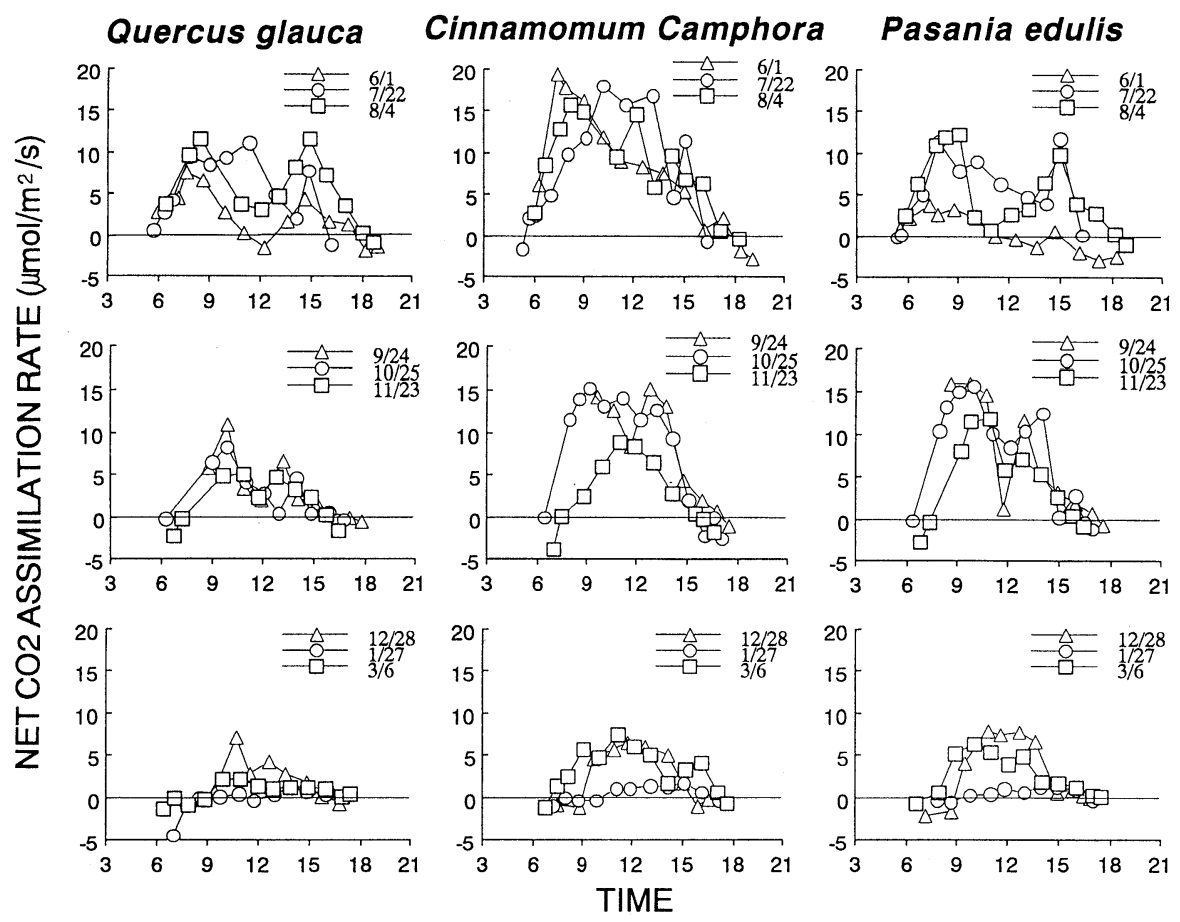

図 3 光合成速度の日変化および季節変化

Fig. 3 Diurnal and seasonal variation of net $\mathrm{CO}_{2}$ assimilation rate

\section{Quercus glauca Cinnamomum Camphora Pasania edulis}

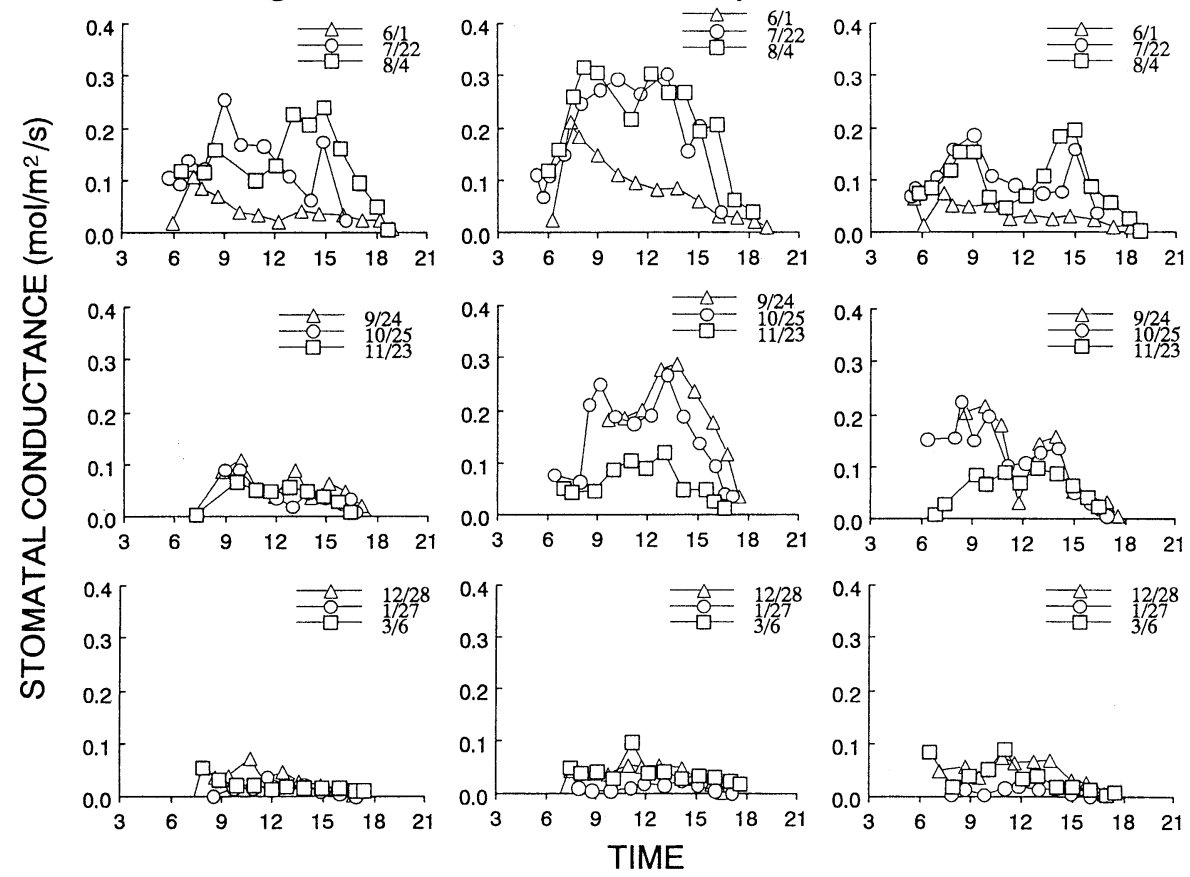

図 4 気孔コンダクタンス $\mathrm{g}_{\mathrm{sc}}$ の日変化および季節変化

Fig. 4 Diurnal and seasonal variation of stomatal conductance for $\mathrm{CO}_{2}$ diffusion $\left(\mathrm{g}_{\mathrm{sc}}\right)$ 


\section{4. 考察}

\section{$4.1 \mathrm{~g}_{\mathrm{i}}$ モデルの適用}

測定から得られた蒸散速度および光合成速度の日変動 パターンは, 日中にピークのある蒸散速度に比べ光合成 速度は午前中に最大值を持ち，その後次第に低下する傾
向があった。そこで，7月22日および10月25日の観測を 例にとってアラカシ，クスノキ，マテバシイの各葉につ いて，横軸に光量子量，縦軸に光合成速度をとった光一 光合成関係のグラフを図 5 に示した。図のように，午前 中の光合成速度が午後に比べて大きくなる結果，光一光 合成関係のグラフはヒステリシスを持つことがわかる。

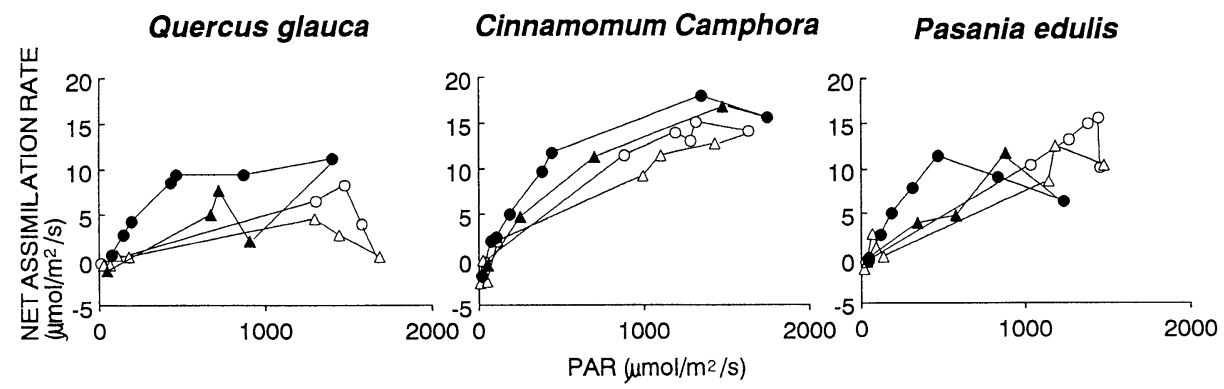

図 57 月22日，10月25日における光-光合成関係 図は左からアラカシ，クスノキ，マテバシイ

○：7月22日午前 $\boldsymbol{\Delta} ： 7$ 月22日午後 $\bigcirc ： 10$ 月25日午前 $\triangle ： 10$ 月25日午後

Fig. 5 The relationship between net $\mathrm{CO}_{2}$ assimilation rate and photosynthetically active radiation (PAR) on July 22 and October 25

: July 22 A.M.

ム : July 22 P.M. $\bigcirc$ : October 25 A.M. $\triangle$ : October 25 P.M.

Quercus glauca Cinnamomum Camphora Pasania edulis

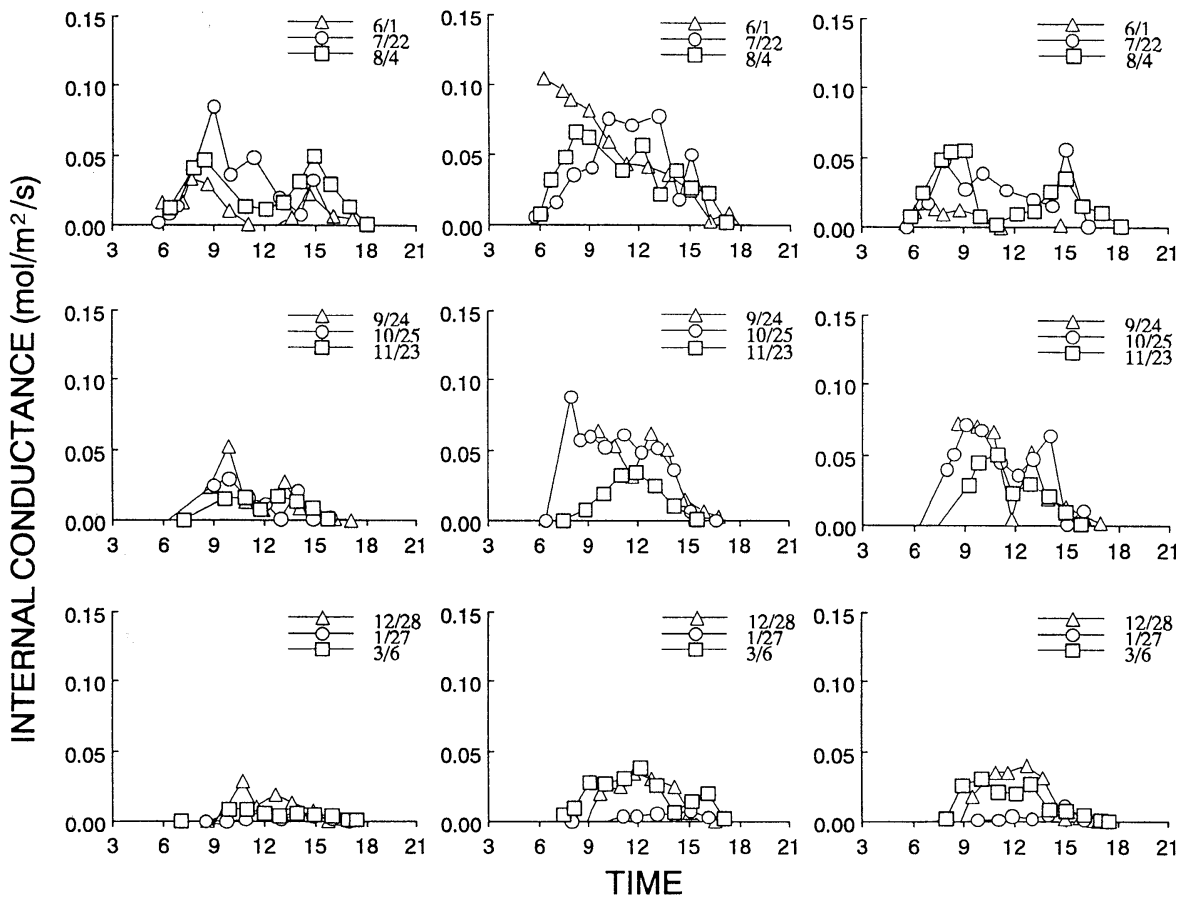

図 6 葉内コンダクタンス $g_{i}$ の日変化および季節変化

Fig. 6 Diurnal and seasonal variation of internal conductance $\left(\mathrm{g}_{\mathrm{i}}\right)$ 
これは同じ光の量でも午前と午後で光合成速度が違うた めである。この原因として午後の場合，(1)気孔が閉じた ために材料の二酸化炭素が少なくなって光合成速度が制 御された，もしくは(2)気孔の開度は材料の供給に十分だ が, 温度やその他の影響でカルビン回路の活性が落ちる, もしくは暗呼吸速度が増えるために光合成速度が制御さ れた，という二つの場合が考えられる。(1)は気孔コンダ クタンスの制御で(2)は葉内コンダクタンスの制御であ る。光合成過程を(1)が打もに制御している場合は蒸散と 光合成の日変化パターンが気孔コンダクタンスのみで説 明できるが，(2)の制御が大きいと光合成の日変化は独立 した動きになる。

そこでこの評価をするために，前述の各樹種の測定結 果について $\Gamma_{*}=40 \mathrm{ppm}$ を用いて実際に葉内コンダクタ ンス $\mathrm{g}_{1}$ を算出し, 図 6 にこの結果を示した。図は左から アラカシ, クスノキ，マテバシイの葉内コンダクタンス の日変化および季節変化を表している。図の緹軸の単位 は図 4 の気孔コンダクタンスと同じ $\mathrm{mol} / \mathrm{m}^{2} / \mathrm{sec}$ で表し た。さらに，図７に，気孔コンダクタンスと光合成速度
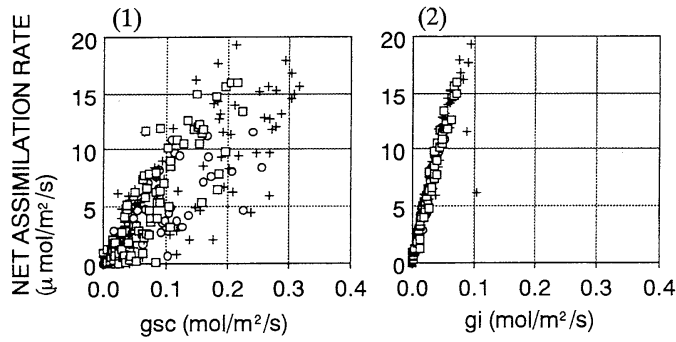

図 7 気孔コンダクタンス $\mathrm{g}_{\mathrm{sc}}$ および葉内コンダクタン ス $\mathrm{g}_{\mathrm{i}}$ と光合成速度の関係

(1)気孔コンダクタンス (2)葉内コンダクタンス ○:アラカシ + : クスノキ $\square:$ マテバシイ

Fig. 7 The relationship between stomatal or internal conductance and net $\mathrm{CO}_{2}$ assimilation rate

(1) stomatal conductance

(2) internal conductance

$\bigcirc$ : Quercus glauca

+ : Cinnamomum camphora

$\square$ : Pasania edulis

(1)TRANSPIRATION RATE

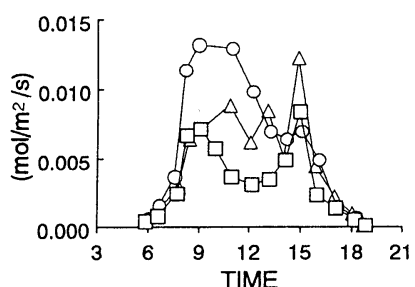

(4)STOMATAL CONDUCTANCE

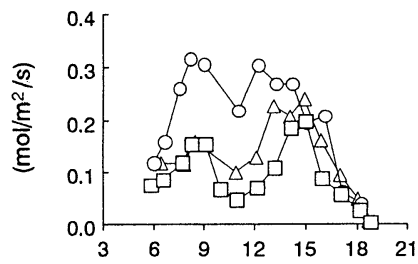

(2)NET ASSIMILATION RATE

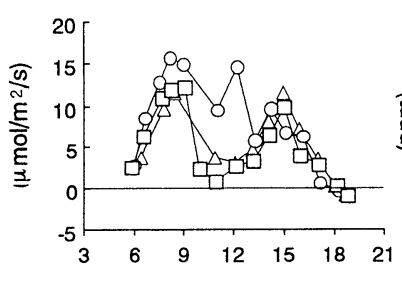

(5)INTERNAL CONDUCTANCE

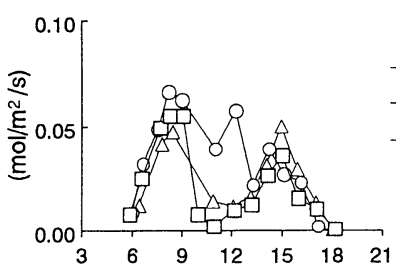

(3)INTERCELLULAR $\mathrm{CO}_{2}$

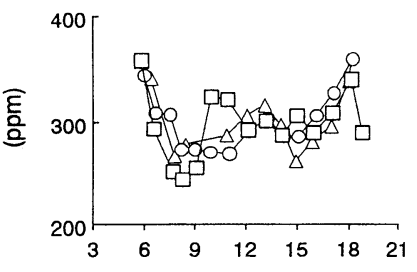

図 88 月 4 日の蒸散速度, 光合成速度, 細胞間隙 $\mathrm{CO}_{2}$ 濃度, 気孔コンダクタンス, 葉内コンダクタンスの経時変化

(1)蒸散速度 $\left(\mathrm{mol} / \mathrm{m}^{2} / \mathrm{s}\right)$ (2)光合成速度 $\left(\mu \mathrm{mol} / \mathrm{m}^{2} / \mathrm{s}\right)$

(3)細胞間隙 $\mathrm{CO}_{2}$ 濃度 $(\mathrm{ppm}) \quad(4)$ 気孔コンダクタンス $\left(\mathrm{mol} / \mathrm{m}^{2} / \mathrm{s}\right)$

(5)葉内コンダクタンス $\left(\mathrm{mol} / \mathrm{m}^{2} / \mathrm{s}\right)$

$\triangle$ :アラカシ $\bigcirc$ :クスノキ $\square:$ ママデシイ

Fig. 8 Diurnal variation of transpiration rate, net $\mathrm{CO}_{2}$ assimilation rate, intercellular $\mathrm{CO}_{2}$ concentration, stomatal conductance and internal conductance on August 8, 1989

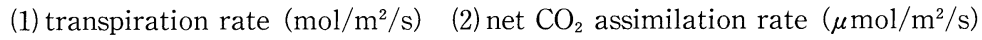

(3) intercellular $\mathrm{CO}_{2}$ concentration ( $\mathrm{ppm}$ ) (4) stomatal conductance $\left(\mathrm{mol} / \mathrm{m}^{2} / \mathrm{s}\right)$

(5) internal conductance $\left(\mathrm{mol} / \mathrm{m}^{2} / \mathrm{s}\right)$ 
それぞれ示した。葉内コンダクタンスは気孔コンダクタ ンスと比較すると大抵の場合かなり小さい值をとること がわかる。また, 光合成速度との相関も非常に高く, 朝 方ピークを持ち, 午後は低下する傾向にあることがわか る。このことは葉内コンダクタンスによる光合成速度の 制御の割合が意外に大きいことを示している。

さらにこの点を詳しく見るため, 真夏日の 8 月 4 日の データを取り上げて，この日の日中低下が気孔閉鎖によ るものか，あるいは光合成活性の低下や呼吸の増加とい った葉内の生理要因によるものかを考察した。図 8 に 8 月 4 日のアラカシ, クスノキ, マテバシイの蒸散速度, 光合成速度, 細胞間隙 $\mathrm{CO}_{2}$ 濃度, 気孔コンダクタンス, 葉内コンダクタンスの経時変化を取り上げて示した。こ の日はアラカシ, マテバシイの光合成速度に日中低下が みられ, 特に低下の激しかったマテバシイでは蒸散速度 の日中低下も見られた。アラカシ，マテバシイではこれ に伴って気孔コンダクタンスおよび葉内コンダクタンス も低下し, 特に葉内コンダクタンスの低下が著しかった。 また細胞間隙 $\mathrm{CO}_{2}$ 濃度はこれらの現象に伴ってかえっ て若干増加する傾向がみられた。一方クスノキでは目立 った低下は見られなかった。ここで各パラメータの光合 成速度への寄与度をみるために, 観測で得られたパラメ ータの一部を変化させてシミュレーションを行った。図 9 に, それぞれの樹種について気孔コンダクタンスを $0.35 \mathrm{~mol} / \mathrm{m}^{2} / \mathrm{s}, 1.0 \mathrm{~mol} / \mathrm{m}^{2} / \mathrm{s}, 0.05 \mathrm{~mol} / \mathrm{m}^{2} / \mathrm{s}, 0.01$ $\mathrm{mol} / \mathrm{m}^{2} / \mathrm{s}$, または葉内コンダクタンスを $0.01 \mathrm{~mol} / \mathrm{m}^{2} /$ $\mathrm{s}, 0.1 \mathrm{~mol} / \mathrm{m}^{2} / \mathrm{s}$ に変化させて, 光合成速度の推定を行っ た結果を示した。気孔コンダクタンスの低下による影響 で光合成速度が低下するといった現象は, 気孔コンダク タンスが $0.05 \mathrm{~mol} / \mathrm{m}^{2} / \mathrm{s}$ を下回るような場合にみられ, 図 8 の気孔コンダクタンスをみるとマテバシイがこれに あてはまる。しかし仮に気孔コンダクタンスを 0.35 $\mathrm{mol} / \mathrm{m}^{2} / \mathrm{s}$ ないし $1.0 \mathrm{~mol} / \mathrm{m}^{2} / \mathrm{s}$ と大きな值として気孔 が開いた状態を仮定しても, 葉内コンダクタンスが非常 に小さい值だったため日中の光合成速度は回復しない。 一方葉内コンダクタンスを $0.1 \mathrm{~mol} / \mathrm{m}^{2} / \mathrm{s}$ と大きな值に すると日中の光合成速度はある程度回復することがわか る。このことはアラカシにもあてはまる。これらのこと から, 8 月 4 日の光合成速度の急激な日中低下は, 気孔 の閉鎖による $\mathrm{CO}_{2}$ 不足よりも, 高温等の原因による光合 成活性の直接の低下や呼吸の増加がひきおこしたものと 考えられる。図 8 の細胞間隙 $\mathrm{CO}_{2}$ 濃度をみても, 日中低 下のおこっているところではかえって増加する傾向にあ り, $\mathrm{CO}_{2}$ 不足の状態でなかったことがわかる。もちろん この場合でも気孔コンダクタンスの低下には不必要な水 の損失を防ぐという重要な意味があり,マテバシイでは, 光合成速度が落ちるのに伴って気孔を閉じて不必要な蒸 散を防いだ結果, 蒸散速度も低下したことが図 8 からう かがえる。

以上の考察から, 今回の観測のように特に厳しい乾燥 条件下にない温暖湿潤な立地の樹木では, 気孔閉鎖に先 導された光合成速度の激しい低下はみられず, 光合成速
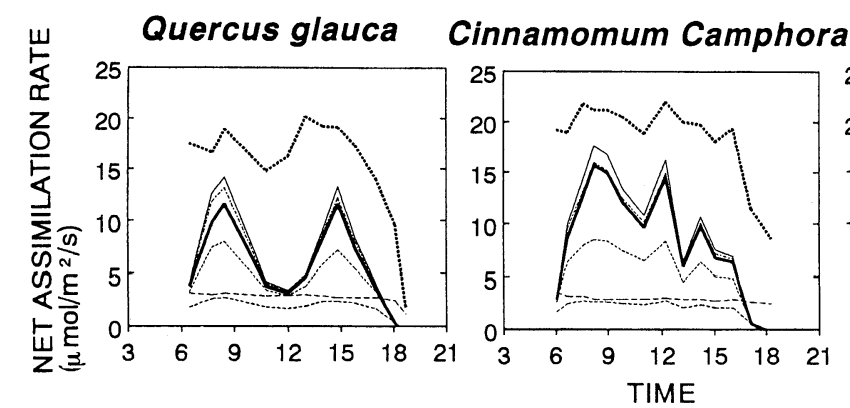

Pasania edulis

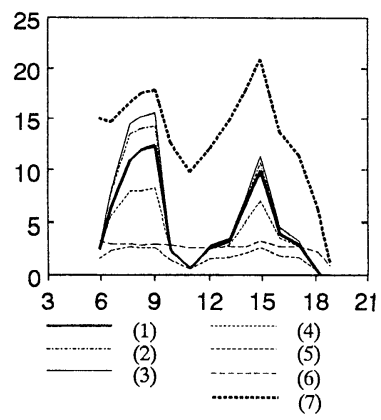

図 98 月 4 日において気孔コンダクタンス, 葉内コンダクタンスを変化させた場合の光合成速度の変化 図は左からアラカシ，クスノキ，マテバシイ

(1)実測值 (2) $\mathrm{g}_{\mathrm{sc}}=0.35 \mathrm{~mol} / \mathrm{m}^{2} / \mathrm{s} \quad$ (3) $\mathrm{g}_{\mathrm{sc}}=1.0 \mathrm{~mol} / \mathrm{m}^{2} / \mathrm{s} \quad$ (4) $\mathrm{g}_{\mathrm{sc}}=0.05 \mathrm{~mol} / \mathrm{m}^{2} / \mathrm{s}$

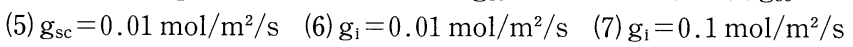

Fig. 9 Simulation of net $\mathrm{CO}_{2}$ assimilation rate on August 8 using constant $\mathrm{g}_{\mathrm{sc}}$ or $\mathrm{g}_{\mathrm{i}}$ values

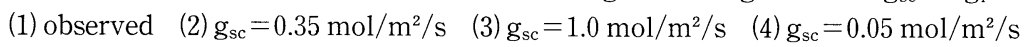

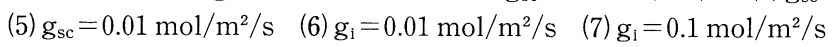




\section{Quercus glauca}

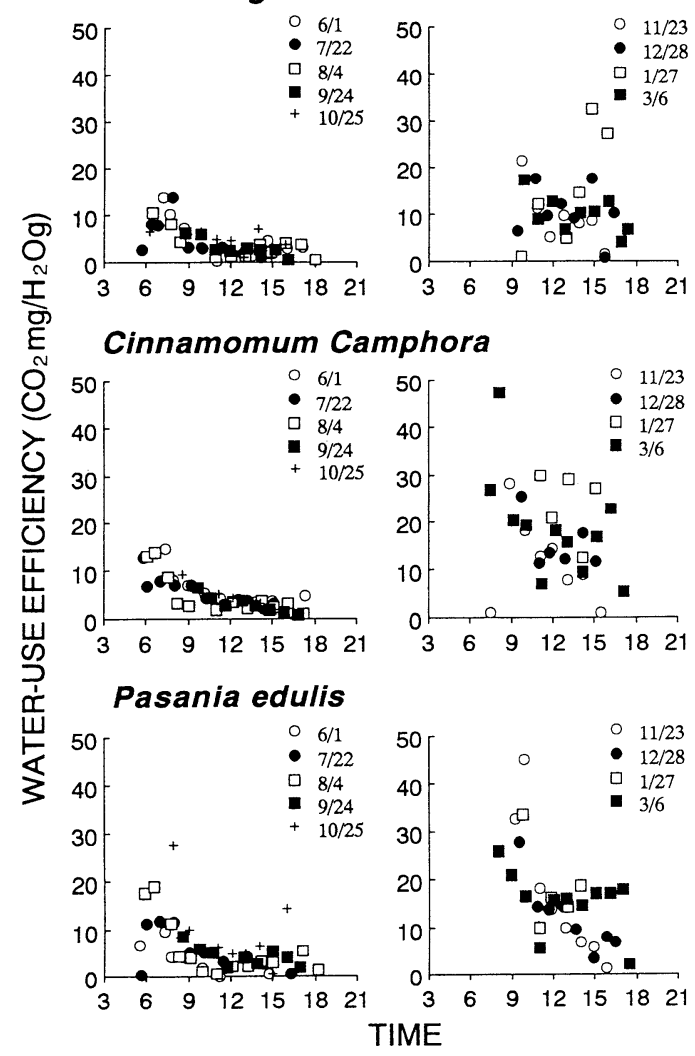

図 10 水利用効率の日変化抢よび季節変化

図は上からアラカシ，クスノキ，マテバシイ。図 11, 図12も同様。

Fig. 10 Diurnal and seasonal variation of water-use efficiency (WUE)

度は葉の呼吸や光合成活性といった要因に大きく左右さ れるということが明らかになった。

\section{2 水利用効率による考察}

次に, 水利用効率と $g_{i}$ モデルを用いて, 光合成および 蒸散速度の日変化および季節変化のパターンはどのよう な環境要因または生理要因によっておもに決定されてい るのかを考察する。

水利用効率は光合成速度 $\left(\mathrm{mg} / \mathrm{m}^{2} / \mathrm{s}\right)$ を蒸散速度 $(\mathrm{g} /$ $\mathrm{m}^{2} / \mathrm{s}$ ) で割った值である。図10にアラカシ, クスノキ, マテバシイ各葉の水利用効率の日変化扔よび季節変化を 示した。水利用効率はどの樹種でも午前中は午後より大 きく，また冬のほうが夏より大きいという傾向がみられ た。このような水利用効率の変化のパターンは, 前章で みたような蒸散および光合成速度の日変化および季節変 化のパターンの違いをうまく表現していると考えられ

\section{Quercus glauca}
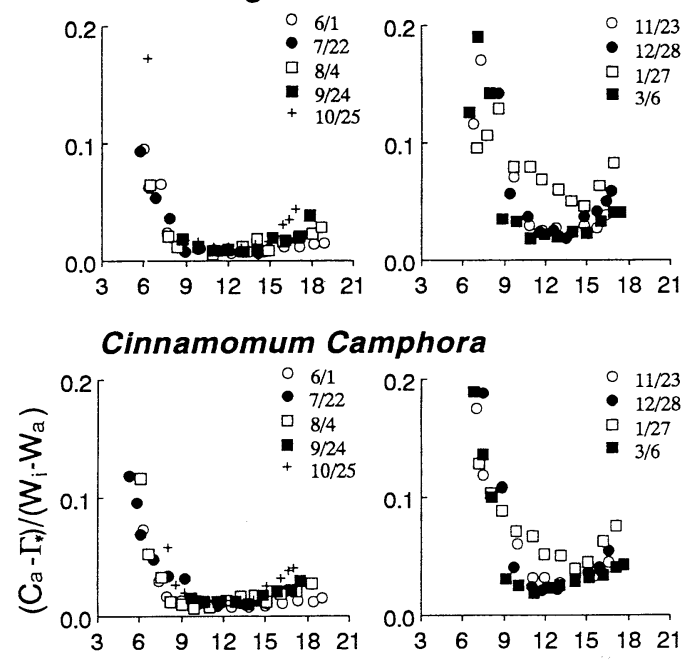

Pasania edulis

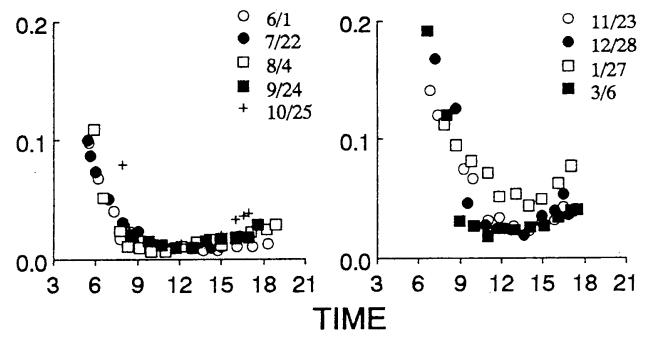

図 11 濃度勾配比 $\left(\mathrm{C}_{\mathrm{a}}-\Gamma_{*}\right) /\left(\mathrm{W}_{\mathrm{i}}-\mathrm{W}_{\mathrm{a}}\right)$ の日変化およ び季節変化

Fig. 11 Diurnal and seasonal variation of $\left(C_{a}-\Gamma_{*}\right) /$ $\left(W_{i}-W_{a}\right)$

る。また，多く蒸散するクスノキや秋のマテバシイでは 光合成も活発なので,この結果 3 樹種とも同じような水 利用効率が得られた。

ところで，水利用効率 WUE (mg/g) は，(1)(3)式を用 いて次式のように分解できる。

$$
\begin{aligned}
& \begin{aligned}
\text { WUE } & =44 \mathrm{~A} / 18000 \mathrm{E} \\
& =44 / 18000\left\{\left(\mathrm{C}_{\mathrm{a}}-\Gamma_{*}\right) /\left(\mathrm{W}_{\mathrm{i}}-\mathrm{W}_{\mathrm{a}}\right)\right\}\left(\mathrm{g}_{\mathrm{tc}} / \mathrm{g}_{\mathrm{tw}}\right)
\end{aligned} \\
& \begin{aligned}
\mathrm{g}_{\mathrm{tc}}= & \frac{\mathrm{g}_{\mathrm{bc}} \cdot \mathrm{g}_{\mathrm{sc}} \cdot \mathrm{g}_{\mathrm{i}}}{\mathrm{g}_{\mathrm{bc}} \cdot \mathrm{g}_{\mathrm{sc}}+\mathrm{g}_{\mathrm{sc}} \cdot \mathrm{g}_{\mathrm{i}}+\mathrm{g}_{\mathrm{i}} \cdot \mathrm{g}_{\mathrm{bc}}} \\
\mathrm{g}_{\mathrm{tw}}= & \frac{\mathrm{g}_{\mathrm{bw}} \cdot \mathrm{g}_{\mathrm{sw}}}{\mathrm{g}_{\mathrm{bw}}+\mathrm{g}_{\mathrm{sw}}}
\end{aligned}
\end{aligned}
$$

この式で第一項 $\left(\mathrm{C}_{\mathrm{a}}-\Gamma_{*}\right) /\left(\mathrm{W}_{\mathrm{i}}-\mathrm{W}_{\mathrm{a}}\right)$ は $\mathrm{CO}_{2}$ と $\mathrm{H}_{2} \mathrm{O}$ の 濃度勾配の比を表しており, 第二項 $\mathrm{g}_{\mathrm{tc}} / \mathrm{g}_{\mathrm{tw}}$ は $\mathrm{CO}_{2}$ と $\mathrm{H}_{2}$ $\mathrm{O}$ の拡散についての全コンダクタンスの比を表してい る。

第一項と第二項のどちらが図10に示したような水利用 
効率のパターンを生み出しているのかを見るために，図 11に第一項の濃度勾配比の日変化および季節変化, 図 12 に第二項の全コンダクタンス比の日変化拉よび季節変化 をそれぞれの樹種について算出したものを示した。眓11 の濃度勾配比は早期に非常に大きく正午ごろ最低となり 午後に少し回復するという特徴, また冬は夏に比べてか なり大きいという特徵が見られた。図12の全コンダクタ ンス比は日変化はだいたい午前中にピークを持つ山形と なり，冬は夏よりやや大きめの值をとる。このことから， 水利用効率の午前中は午後より大きいという日変化のパ ターンは早朝の大きな濃度勾配比とその後の全コンダク タンス比の増加に影響されており，冬のほうが夏より大 きいという季節変化のパターンは扔もに濃度勾配比にそ の原因があることがわかった。

さらに全コンダクタンス比の変化がどのような意味を 持つかを考察するために，図13に横軸に葉内コンダクタ ンス $\mathrm{g}_{\mathrm{i}} /$ 気孔コンダクタンス $\mathrm{g}_{\mathrm{sc}}$, 縦軸に全コンダクタン

\section{Quercus glauca}
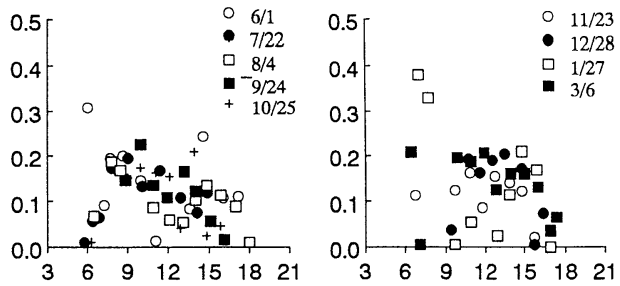

Cinnamomum Camphora
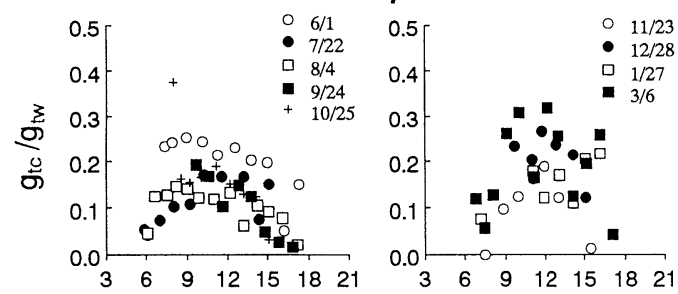

Pasania edulis

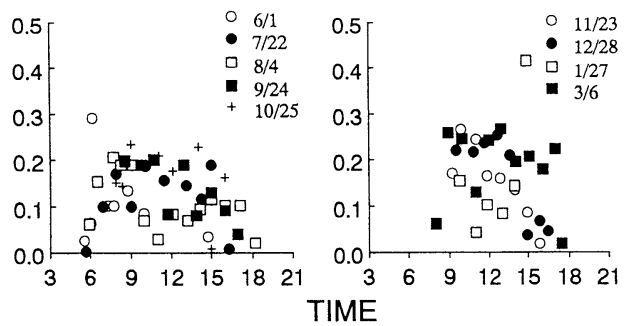

図 12 全コンダクタンス比 $g_{t c} / g_{t w}$ の日変化抢よび季節 変化

Fig. 12 Diurnal and seasonal variation of $g_{t c} / g_{t w}$

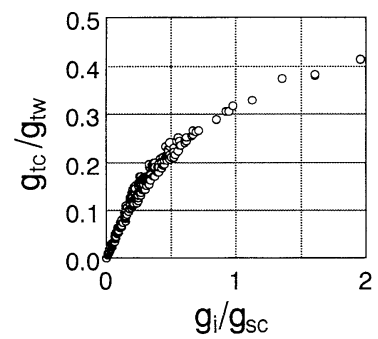

図 $13 \mathrm{~g}_{\mathrm{i}} / \mathrm{g}_{\mathrm{sc}}$ と $\mathrm{g}_{\mathrm{tc}} / \mathrm{g}_{\mathrm{tw}}$ の関係

Fig. 13 The relationship between $g_{i} / g_{s c}$ and $g_{t c} / g_{t w}$

ス比 $\mathrm{g}_{\mathrm{tc}} / \mathrm{g}_{\mathrm{tw}}$ をとり,すべての観測データをプロットして 相関を示した。全コンダクタンス比が大きいということ は $\mathrm{g}_{\mathrm{i}} / \mathrm{g}_{\mathrm{sc}}$ が大きいことになり, 気孔開度の割に葉による 二酸化炭素取り込み効率が高いことを表しているといえ る。

これらの結果を総合すると，次のことが明らかになっ た。まず, 光合成の冬の低下が蒸散ほど著しくないのは, おもに $\mathrm{H}_{2} \mathrm{O}$ の濃度勾配（飽差）が夏と冬で顕著に違い, 一方 $\mathrm{CO}_{2}$ の濃度勾配のほうはそれほど季節変化をしな いといった大気の要因による。また，日変化において蒸 散速度は正午ごろピークをもつのに対し光合成が朝方ピ 一クを持つため水利用効率が朝のほうが午後より大きく なるのは, 朝のほうが飽差が小さいという大気の要因, 午前中は気孔開度の割に葉による二酸化炭素取り込み効 率が高いという植物の要因の両方によることがわかっ た。

\section{5. おわりに}

気孔コンダクタンスおよび葉内コンダクタンスはどち らもガス拡散という物理現象に対する植物の自律的制御 を表現しているが, 蒸散速度については気孔コンダクタ ンスのみが制御要因になるのに対して，光合成速度につ いては気孔コンダクタンスと葉内コンダクタンスがとも に制御要因となると考えられる。二つのコンダクタンス を分離し，比較することによって両者の寄与度について 検討をおこない，また水利用効率を用いた考察によって 蒸散および光合成速度の日変動抽よび季節変動パターン が大気拉よび植物のどの要因に起因するのかを説明する ことができた。

蒸散速度と光合成速度がどの程度連動するのかという 問題はモデリングを考える上で非常に重要な点である が, 定性的には植物は気孔開度を最小に保つことによっ て最小の蒸散速度で最大の光合成速度を得るようにふる まうとされている。しかし本研究で用いた常緑広葉樹の 
例のように水分的に恵まれた条件の下では植物は気孔開 度を最小值より大きめに設定しており，この結果光合成 速度は蒸散速度とある程度独立して決定されているよう である。異なる環境条件下，また異なる樹種ではどのよ うな結果になるのかが非常に興味深い点である。

なお, 本研究の一部は平成 5 年度文部省科学研究費補 助金 (特別研究員奨励費) を受けて行われた。

\section{参考文献}

1) von CAEMmerer, $\mathrm{S}$ and Evans, J.R.: Determination of average partial pressure of $\mathrm{CO}_{2}$ in chloroplasts from leaves of several $\mathrm{C}_{3}$ plants, Aust. J. Plant Physiol. 18, 287-305, 1991

2) Chartier, P. Chartier, M and Catsky, J. : Resistances for carbon dioxide diffusion and for carboxylation as factors in bean leaf photosynthesis, Photosynthetica 4, 48-57, 1970

3) FArquhar, G.D., von CAEMmerer, S. and BERry, J. A.: A biochemical model of photosynthetic $\mathrm{CO}_{2}$ assimilation in leaves of $\mathrm{C}_{3}$ species, Planta 149, 78-90, 1980
4) FARquhar, G.D. and Sharkey, T.D : Stomatal conductance and Photosynthesis, Ann. Rev. Plant Physiol. 33, 317-345, 1982

5）花山秀文・柴田昌三：数種の常緑緑化樹種における光合 成速度と気孔コンダクタンスの季節変化について, 第 21 回緑化工研究発表会要旨集，30-33，1990

6) KIRSChBAUM, M.U.F and FARQUHAR, G.D. : Temperature dependence of whole-leaf photosynthesis in Eucalyptus pauciflora Sieb. et Spreng, Aust. J. Plant Physiol. 11, 519-538, 1984

7）近藤純正：大気境界層の化学, 東京堂出版, pp. 219, 1982

8) Jones, H.G. and Slatyer, R.O.: Estimation of the transport and carboxylation components of the intracellular limitation to leaf photosynthesis, Plant Physiol. 50, 283-288, 1972

9）柴田昌三・小橋澄治・花山秀文：土䁃水分および気温が 常緑広葉樹の光合成活動に与える影響, 日本緑化工学会 誌17(1)，1-8，1991

10）島田緑子：光合成・蒸散過程の統合的理解について(1)光 合成モデルと気孔開閉の仕組み, 日本緑化工学会誌 17(4)，224-235，1992

11）島田緑子・福留昭彦・鈴木雅一：数種常緑広葉樹の光合 成・蒸散速度の日変化について, 第23回緑化工研究発表 会要旨集, 36-39, 1992

(1994. 2.28受理)

\section{Summary}

To explain the process of $\mathrm{CO}_{2}$ and $\mathrm{H}_{2} \mathrm{O}$ diffusion between air and plant, analysis was made using a data set concerned with diurnal and seasonal variation of transpiration and net $\mathrm{CO}_{2}$ assimilation rate on leaves of three evergreen broad-leaved trees (Quercus glauca, Cinnamomum camphora and Pasania edulis). The observation results about the pattern of diurnal and seasonal change are as follows: (1) Diurnal variation: the pattern of transpiration rate had the peak about at noon, whereas the pattern of net $\mathrm{CO}_{2}$ assimilation rate had the peak in the morning. (2) Seasonal variation: bigger seasonal variation in transpiration rate compared with net $\mathrm{CO}_{2}$ assimilation rate were observed. (3) Water-use efficiency : the values are higher in the morning or in winter than in the afternoon or in summer. Two parameters, stomatal conductance and internal conductance, were used to explain the observation results. From this analysis it is shown quantitatively that stomatal conductance is not the single physiological component deciding $\mathrm{CO}_{2}$ flux and the influence of internal conductance is not negligible. Moreover, it could be explained by analyzing water-use efficiency which environmental and plant factor mainly caused the differences of the pattern of the diurnal and seasonal variation between transpiration rate and net $\mathrm{CO}_{2}$ assimilation rate. 